\title{
SYNTHESIS OF AMIDOXIMES USING AN EFFICIENT AND RAPID ULTRASOUND METHOD
}

\author{
CARLOS JONNATAN PIMENTEL BARROS, JUCLEITON J. RUFINO DE FREITAS, \\ RONALDO N. DE OLIVEIRA, JOÃO R. DE FREITAS FILHO $*$
}

${ }^{a}$ Departamento de Química, Universidade Federal de Rural de Pernambuco. Av. Dom Manoel de Medeiros, s/n, 52171-900, Recife, PE, Brazil.

(Received: March 1, 2011 - Accepted: May 11, 2011)

\begin{abstract}
This is a report on an efficient and rapid synthesis of amidoximes using ultrasound irradiation with appropriate nitrile and hydroxylamine hydrochloride in water/ethanol. This new synthetic methodology is compared with previously known methods. The main advantages of the process reported are shorter reaction times, easier work-up, and good yield.
\end{abstract}

Keywords: Amidoximes, nitrile, irradiation, ultrasonic

\section{INTRODUCTION}

The name amidoxime was first used by Tiemann ${ }^{1}$, who identified the structure of this class of compounds in 1884. Amidoximes constitute an important class of compound ${ }^{2,3}$ in their own right and have been employed for the synthesis ${ }^{2-6}$ of a variety of valuable compounds. Their importance in chemistry, along with their rich biology, makes amidoximes an attractive target for medicinal chemists, biochemists and biologists?

Amidoximes have exhibited important biological activities, for example, as antitripanocidics ${ }^{8}$, antituberculotics ${ }^{9,10}$, hypotensives and antiarrhythmics ${ }^{11}$, antibacterials and fungicidals ${ }^{12}$. Amidoxime have been tested for pharmacological properties and have been found to be useful as local anaesthetics ${ }^{13}$, fibrinogen receptor antagonists ${ }^{14}$, and as antileishmanial agents ${ }^{15}$. A number of amidoximes have already been used as prodrugs for amidines ${ }^{16}$, or are currently being used in clinical trials ${ }^{7}$. Many recent pharmaceutical applications have been enriched, with some of their mechanistic pathways converted to amidines, as well as clarification of their ability to release NO providing insight into their mode of action and allowing the design of new therapeutic agents ${ }^{7}$. The nitrogen oxide generated functions as mediator in regulating diverse physiological processes such as blood pressure, neurotransmission, learning, memory, and immunomodulation ${ }^{17,18}$.

Recently, a paper was published describing the synthesis of alkyl and arylamidoximes in good yields using hydroxylamine hydrochloride and appropriate nitrile in water/ethanol with continued stirring at $25{ }^{\circ} \mathrm{C}$ for 20 $\mathrm{h}^{19}$. The study of an efficient and rapid synthesis of alkyl and arylamidoximes using ultrasound irradiation from of appropriate nitrile and hydroxylamine hydrochloride is reported here. A survey of the literature shows that many organic reactions have been accelerated using ultrasonic irradiation ${ }^{20-22}$.

\section{EXPERIMENTAL}

General consideration:

Melting points were determined using an Electrothermal digital melting points apparatus (model IA9100) and uncorrected. IR spectra were recorded as $\mathrm{KBr}$ films on a Brucker IFFS66 series Fourier transform spectrophotometer. ${ }^{1} \mathrm{H}$ and ${ }^{13} \mathrm{C}$ NMR spectra were recorded on a Bruker DPX 400 spectrometer at $400 \mathrm{MHz}$ and $100 \mathrm{MHz}$, respectively, using DMSO- $d_{6}$ as solvent and $\mathrm{Me}_{4} \mathrm{Si}$ as the internal standard. Chemical shifts are reported in ppm. Coupling constants are reported in Hz. Thin Layer Chromatography (TLC) was performed using Merck Silica gel $60 \mathrm{~F}_{254}$ Plates. Sonication was performed using a Model USC$1400 \mathrm{~A}$ utracleaner with a frequency of $40 \mathrm{kHz}$.

General experimental procedure for the synthesis of alkyl and arylamidoximes (3a-j)

Hydroxylamine hydrochloride ( $2.0 \mathrm{~g}, 29.1 \mathrm{mmol}), 2.4 \mathrm{~g}$ sodium carbonate ( $29.1 \mathrm{mmol}$ ) and $25.0 \mathrm{~mL}$ water were used at room temperature followed by the addition of $3.0 \mathrm{~g}$ benzonitrile $(29.1 \mathrm{mmol})$ in $25.0 \mathrm{~mL}$ ethanol. The reaction mixtures were irradiated with an ultrasound probe for 15 and 30 minutes an temperature of $55^{\circ} \mathrm{C}$ (the reaction was monitored by TLC). Concentration by rotary evaporation at reduced pressure gave a mixture of a colorless oil which were dissolved in $50 \mathrm{~mL}$ of dichloromethane, dried $\left(\mathrm{Na}_{2} \mathrm{SO}_{4}\right)$, filtered, and the solvent removed under reduced pressure. The crude product was recrystallized using chloroform-hexane to produce pure alkyl or arylamidoximes.

The spectroscopic data of all synthesized compounds match with the reported values: $\mathbf{3} \mathbf{a} \mathbf{b}^{23}, \mathbf{3} \mathbf{c}-\mathbf{h}^{19}, \mathbf{3 i}^{24}, \mathbf{3 j}^{6}$.

\section{RESULTS AND DISCUSSION}

Alkyl and arylamidoximes are prepared by treating the corresponding alkyl and arylnitriles with hydroxylamine hydrochloride in the presence of base afforded the compounds 3a-j (Scheme 1) under ultrasonic irradiation. This reaction was monitored by TLC. The important point in this synthesis include the easier work-up, higher yields and shorter reaction time than the conventional method. The results are depicted in Table 1.

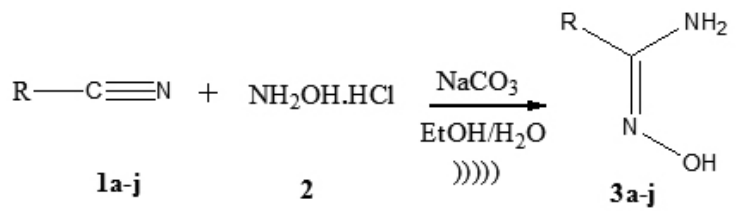

$\mathrm{R}=$ Alkyl ou aryl

$\begin{array}{ll}\text { a: } \mathrm{Me} & \text { f: } o \text {-tolyl } \\ \text { b: } n \text { - } \mathrm{Pr} & \text { g: } p \text {-ClPh } \\ \text { c: } \mathrm{Ph} & \text { h: } p \text { - } \mathrm{BrPh} \\ \text { d: } p \text {-tolyl } & \text { i: } m \text { - } \mathrm{BrPh} \\ \text { e: } m \text {-tolyl } & \text { j: } p-\mathrm{NO}_{2} \mathrm{Ph}\end{array}$

Scheme 1: Synthesis of alkyl and arylamidoximes

The mechanism of formation of the compounds (3a-j) and the optimized geometries are described in the literature ${ }^{19}$.

According to the literature ${ }^{19}$, hydroxylamine is an ambident nucleophile, so either the oxygen or nitrogen atom of this molecule may attack the nitrle carbon atom, which behaves as a moderately hard acid. Since a strong base would prefer to bind with a strong acid, it is our conviction that the oxygen atom attacks the carbon atom of the nitrile group preferentially and that this reaction is kinetically controlled.

The reaction presented a useful range of applications, furnishing the desired products in high yields. Arylamidoximes containing a methyl group at meta or para positions react similarly while orto tolylamidoxime (3f) undergoes a reaction furnishing a lesser yield of the desired product $(40 \%)$ probably due to steric hindrance. The presence of electron-withdrawing and electron-donating groups attached to the para position of arylamidoximes is well tolerated by the reaction. 
Table 1. Synthesis of alkyl and arylamidoxime (3a-j) using ultrasound irradiation.

\begin{tabular}{|c|c|c|c|c|c|c|}
\hline Entry & Nitrile & Products & \multicolumn{2}{|c|}{$\begin{array}{c}\text { Conventional } \\
\text { Method }\end{array}$} & \multicolumn{2}{|c|}{$\begin{array}{c}\text { Ittrasound } \\
\text { Method }\end{array}$} \\
\hline & & & $\begin{array}{c}\text { Time } \\
\text { (hour) }\end{array}$ & $\begin{array}{c}\text { Yield } \\
\text { (\%) }\end{array}$ & $\begin{array}{c}\text { Time } \\
\text { (min) }\end{array}$ & $\begin{array}{c}\text { Yield } \\
\text { (\%) }\end{array}$ \\
\hline 1 & $\mathbf{1 a}$ & $\mathbf{3 a}^{\mathrm{a}}$ & 24 & 79 & 30 & 81 \\
\hline 2 & $\mathbf{1 b}$ & $\mathbf{3 b}^{\mathrm{a}}$ & 24 & 64 & 30 & 72 \\
\hline 3 & $\mathbf{1 c}$ & $\mathbf{3 c}^{\mathrm{b}}$ & 20 & 80 & 15 & 85 \\
\hline 4 & $\mathbf{1 d}$ & $\mathbf{3 d}^{\mathrm{b}}$ & 72 & 89 & 15 & 92 \\
\hline 5 & $\mathbf{1 e}$ & $\mathbf{3 e}^{\mathrm{b}}$ & 72 & 89 & 15 & 90 \\
\hline 6 & $\mathbf{1 f}$ & $\mathbf{3 f}^{\mathrm{b}}$ & 20 & 31 & 30 & 40 \\
\hline 7 & $\mathbf{1 g}$ & $\mathbf{3 g}^{\mathrm{b}}$ & 24 & 73 & 30 & 88 \\
\hline 8 & $\mathbf{1 h}$ & $\mathbf{3 h}^{\mathrm{b}}$ & 24 & 79 & 30 & 91 \\
\hline 9 & $\mathbf{1 i}$ & $\mathbf{3 i}^{\mathrm{c}}$ & $\begin{array}{c}\text { not } \\
\text { reported }\end{array}$ & $\begin{array}{c}\text { not } \\
\text { reported }\end{array}$ & 30 & 75 \\
\hline 10 & $\mathbf{1 j}$ & $\mathbf{3 j}^{\mathrm{d}}$ & 5 & 30 & 30 & 88 \\
\hline
\end{tabular}

${ }^{a}$ Reference ${ }^{23}$; ${ }^{\mathrm{b}}$ Reference ${ }^{18}$; ${ }^{\mathrm{c}}$ Reference ${ }^{24}$; ${ }^{\mathrm{d}}$ Reference ${ }^{6}$.

\section{CONCLUSION}

In conclusion, an efficient and rapid synthesis of alkyl and arylamidoximes under ultrasound irradiation is reported. The final products were obtained in a short time with high yields ( $40 \%-92 \%)$.

\section{REFERENCES}

1.- F. Tiemann, Ber. 17, 126 (1884).

2.- F. Eloy, R. Lenaers, Chem. Rev. 62, 155 (1962).

3.- L. Brandt, Meded. Vlaam, Chem. Ver. 29, 56; Chem. Abstr. 67: 81610g, (1967).

4.- M. B. Brito, R.M. Srivastava, J. Chem. Eng. Data. 30, 131 (1985).

5.- E. Kavashima, K. Tabei, J. Heterocycl. Chem. 23, 101 (1987).

6.- R. M Srivastava, I.M. Brinn, J.O. Machuca-Herrera, H.B. Faria, G.B. Carpenter, D. Andrade, C.G. Venkatesh, L.P.F. de Morais, J. Mol. Struct. 406:159 (1997).
7.- K. C. Fylaktakdou, D. J. Hadjipavlou-Litina, K. E. Litinas, E. A. Varella, D. N. Nicolaides, Curr. Pharm. Des. 14 (10) (2008).

8.- L. D. Lamb, A. C. White, J. Chem. Soc. 1253 (1939).

9.- N. P. Buu-Hoi, M. Welsch, N.D. Xuong, K. V. Thang, Experientia, 10, 169 (1954).

10.- N. P. Buu-Hoi, N.D. Xuong, K. V. Thang, Bull. Soc. Chim. 294 (1954).

11.- D. N. Nicolaides, E. A. Varella, The Chemistry of Acid Derivatives, Vol. 2, John Wiley: New York, 876 (1992).

12.- T. Bandiera, F, M. Albini, E. Albine, J. Heterocycl. Chem, 24, 1597 (1987).

13.- K. Sindelar, Z. Sedivy, M. Hrubantová, M. Valchár, J. Metysová, M. Protiva, Collect. Czech. Chem. Commun. 53, 381 (1988).

14.- D. Middlemiss, B. D. Judkins, C.D. Eldred, B. Porter, H. A. Kelly, PCT Int. Apll. WO 9322, 303 (Cl.C07D295/14), 11 November 1993, GB Appl. 92/8, 740, 23 April 1992, 74p., Chem. Abstr., 120: 217732w.

15.- A. Bouhlel, C. Curti, A. Dumètre, M. Laget, M. D. Crozet, N. Azas, P. Vanelle, Bioorg. Med. Chem. 18, 7310 (2010).

16.- A. R. Katritzky, N. M. Khashab, N. Kirichenko, A. Singh, J. Org. Chem. 71, 9051 (2006). and references herein..

17.- S. Moncada, R. M. J. Palmer, E. A. Higgs, Pharmacol. Rev. 43, 109 (1991).

18.- A. Jousserandot, J. L. Boucher, Y. Henry, B. Niklaus, B. Clement, D. Mansuy, Biochemistry. 37:17179 (1998).

19.- R. M. Srivastava, M. C. Pereira, W. W. M. Faustino, K. Coutinho, J. V. dos Anjos, S. J. de Melo, Monatsh Chem. 140:1319(2009).

20.- L. Luche, Synthetic Organic Sonochemistry, Plenum Press, New York, (1998).

21.- R. M. Srivastava, R. A. W. N. Filho, C. A. Silva, A. Bortoluzzi, Ultrason. Sonochem. 16, 737 (2009).

22.- I. Mohammadpoor-Baltork, M. Moghadam, S. Tangestaninejad, V. Mirkhani, Z. Eskandari, Ultrasonics Sonochemistry. 17, 857 (2010).

23.- W. R. Dolbier Jr, C. R. Burkholder, M. MeÂdebielle, Journal of Fluorine Chemistry. 95, 127 (1999).

24.- J. K. Augustine, V. Akabote, S. G. Hegde, P. Alagarsamy, J. Org. Chem. 74, 5640 (2009)

\section{ACKNOWLEDGMENTS}

The authors are grateful to the Brazilian National Research Council (CNPq), FACEPE and CAPES for financial support. 